\title{
HABLANDO DE DIOS EN FEMENINO
}

\author{
ETHEL KATZ DE BARYLKA \\ Jerusalén, Israel
}

Recibido: 20/8/2012

Aceptado: 08/10/2012

\section{Resumen}

Este artículo incursiona en la visión de las fuentes clásicas y poco conocidas en idioma español redescubriendo la posibilidad de un discurso femenino acerca de Dios. El eje temático gira alrededor de las características masculinas de Dios, visto hasta hace muy poco, únicamente a partir de la descripción teológica llevada a cabo por varones y la posibilidad de otra lectura, esta vez femenina, usando los atributos que en hebreo se adjudicaron a la Divinidad. La aportación más significativa de este trabajo estriba en la re-definición de Dios, como ente masculino-femenino, cuando Adán, fue creado andrógeno bisexual a imagen y semejanza de Dios mismo. Las fuentes midráshicas utilizadas demuestran que el tema estuvo latente durante varios siglos, rescatándose recién en los últimos años a partir de la búsqueda femenina de una fe basada en Dios Uno, con el cual la mujer pueda identificarse más fácilmente por ser parte de ella misma.

Palabras clave: mujer, judaísmo, Dios, midrash, femenino, fe, feminismo judío, teología feminista.

\begin{abstract}
This article ventures into the possibility of a feminine discourse about God, based on the study of the classical sources, which are not widely known in Spanish. The main theme revolves around male characteristics of God, which until recently, are seen only from the theological description carried out by men and the possibility of another reading, this time female, using the attributes that were awarded to Hebrew Divinity. The most significant contribution of this work lies in the re-definition of God as male-female body, when Adam was created androgen bisexual, and in the image of God Himself. The midrashic sources used in this article show that the issue was dormant for centuries, only in recent years rediscover by a female-driven search for
\end{abstract}


faith based upon God One, with which women can more easily identify as being part of a feminine self.

Keywords: woman, Judaism, God, midrash, women, faith, Jewish feminism, feminist theology. 
Dios no es masculino ni femenino. Todo atributo acerca de la identidad sexual de Dios es impensable. Dios, incorpóreo e inmaterial, carece de identidad y de propiedades sexuales. La incorporeidad e intangibilidad de Dios es uno de los principios básicos del pensamiento judaico. Así lo explicitó Maimónides, el médico, rabino y teólogo judío más célebre de la Edad Media (1135, Córdoba, España - 1204, Fustat, Egipto) en su tercer principio de fe «Creo con fe absoluta que el Creador, bendito sea su nombre, es incorpóreo, que no le alcanzan los atributos corporales y carece de imagen alguna $»^{1}$.

\section{Todo lo que puede ser dicho y pensado acerca de Dios puede hacerse tanto en femenino como en masculino.}

Sin embargo, a lo largo de los siglos, el discurso acerca de Dios ha sido predominantemente masculino. Dios ha sido pensado y presentado como varón, por varones, entonces Dios era varón. Dios pensado por la mujer es una figura prácticamente desconocida. Poco o nada sabemos acerca del pensamiento femenino acerca de Dios. Así, la mujer creció con un Dios cuya imagen, atributos y características esenciales son substancialmente masculinos. Dios es padre y esposo, amante, pero nunca madre, hermana o esposa. Más aun, Dios es Dios y no Diosa. Es el Dios y no la «ella» Dios.

A continuación intentaremos abrir una ventana a algunas de las expresiones, metáforas e indicaciones que nos hablan de Dios a partir de la mujer en las fuentes del Pensamiento Judío.

En la cultura y la civilización judía, la palabra ocupa un lugar especial. El Verbo es el instrumento de la Creación. La palabra, así como lo hiciera Adam al otorgar nombre a los animales ${ }^{2}$, es la que define, nombra, delimita y crea.

1. LOS TRECE PRINCIPIOS DE FE de Maimónides, que pueden ser considerados casi el único intento de redacción de un credo judío sistematizado, se encuentran incluidos en los devocionarios de casi todos los judíos y muy especialmente en los del ritual sefardita.

2. GÉNESIS 2:19 Ahora bien, el Eterno Dios estaba formando del suelo toda bestia salvaje del campo y toda criatura voladora de los cielos, y empezó a traerlas al hombre para ver lo que llamaría a cada una; y lo que el hombre la llamaba, a cada alma viviente, ese era su nombre. De modo que el hombre iba dando nombres a todos los animales domésticos y a las criaturas voladoras de los cielos y a toda bestia salvaje del campo... 
El pensamiento teológico no está fuera del lenguaje. El judaísmo no construyó una estructura teológica pura, no se dedicó a teorizar acerca de Dios. Su interés estuvo centrado en la comprensión del mensaje de las Escrituras y la normatividad que surge de ellas, más que a la esencia de Dios. Tanto el debate interpretativo como la discusión normativa se manejaron en lenguaje masculino. La voz de la mujer referida a Dios no fue oída en la larga tradición que fuera recogida en un principio en la Mishná -recopilación que es la base de la transmisión oral- hace ya casi dos milenios. Desde entonces y hasta nuestros días, los participantes activos en esa transmisión fueron exclusivamente hombres. La voz de la mujer no fue recogida ni en los textos básicos ni en la exégesis y, lo más notorio, tampoco en la creación de la normatividad, la Halajá; ni siquiera en las disposiciones referidas a las acciones que se exige de la mujer en cuanto tal. No es de extrañar entonces que el silenciamiento de la voz de la mujer también exista en lo referido a Dios. Sin embargo, el desafío feminista, demanda la búsqueda de un saber y un hablar nuevo y diferente acerca de Dios en sí. Busca cambiar el uso del lenguaje mientras trata de crear una teología femenina o una filosofía propia, a partir de un discurso que pueda ser compartido en su totalidad por el otro género.

El feminismo judío, en sus primeros pasos, se centró en la lucha por una mayor inclusión de la mujer en la esfera religiosa en general, sobre todo, en los aspectos que hacen a la normatividad y el saber. Dado que el judaísmo se caracteriza por ser una religión ritual y un sistema normativo amplio, que abarca todas las áreas de la vida, más que un credo abstracto y teórico, puede entenderse la necesidad del feminismo de atender en primera instancia estas cuestiones concretas y prácticas. A partir de allí, se puede reivindicar el lugar de la mujer en estas dos esferas centrales del judaísmo. Esferas que marcan y determinan el día a día de la mujer judía creyente. La reflexión feminista judía aspiró en una primera etapa más a la inclusión de la mujer en la vida comunitaria y sinagogal que a una nueva lectura de la Ley, la Historia y la Práctica normativa. Pero, sin esa nueva lectura se carece de la base para poder discutir sus temas con quienes tenían hasta hace poco el monopolio de la «verdad» religiosa. Por ello, en los últimos años se ha intensificado el estudio de los textos y la reinterpretación del Talmud y, fundamentalmente, del midrash (abundante en material relativamente poco usado). Allí se encuentran las fuentes para una plegaria femenina significativa, para el accionar femenino en la comunidad, y para la creación de un pensamiento teológico totalmente nuevo que puede tratar también el tema de Dios desde una lectura femenina. No hay en ello la búsqueda de una reforma religiosa sino de una nueva lectura de los textos que se rescatan en nuestros días para recuperar la palabra silenciada. 
Algunos pensadores del siglo XX han llegado por otros caminos del pensamiento a plantear la posibilidad de un Dios comprehensivo de los dos sexos, incluyendo claramente la posibilidad de su carácter femenino. Entre ellos se encuentra Emmanuel Levinas (1906-1995) con su relación ética cara-a-cara, y su aporte fundamental a la otredad:

¿Dios no significa el otro que no es el ser? ¿El pensamiento significante no significa, a imagen de Dios, el estallido, la subversión del ser: un desinter-és (una salida del «es»)? ¿Acaso el otro, irreductible al Mismo, no permite, en una relación concreta (la ética), imaginar ese otro o ese más allá? ${ }^{3}$

Lévinas recorre por su propia senda, la teología dialógica de Martin Buber (Viena,1878-Jerusalén, 1965) que establece la relación Yo-Tú, la de Abraham Joshua Heschel (Varsovia, 1907-Nueva York,1972) cuando explora el pathos de la divina presencia, el existencialismo halájico del talmudista y filósofo Josef Soloveitchik (1903-1993) que desarrolló el concepto del existencialismo en la ortodoxia moderna judía, y las exploraciones de la vida interior subjetiva como un reflejo del drama intradivino de quien fuera el primer gran rabino asquenazí de Israel durante el Mandato Británico, Abraham Isaac Kook (1865, Grīva, hoy Letonia - Jerusalén, Israel 1935).

Cada uno, a su manera, ofreció distintos modos de pensar a Dios que salen de de los límites paternalistas y patriarcales a los que estábamos acostumbrados.

En nuestros días se construye, no sin dificultades, una teología de la cual la mujer es parte tanto como sujeto que reflexiona acerca de Dios como a través del develamiento de sus facetas femeninas. La primer dificultad nace como resultado de pensar un espacio inexistente en la formación de la mujer judía, por lo menos hasta hace medio siglo atrás. Toda la educación de la mujer judía implicaba, y envuelve hasta ahora, un espacio periférico de la mujer a través de las generaciones, que casi no ha sido cuestionado. Lo que se absorbió en la enseñanza, en la lectura y el aprendizaje de los textos recibía la canonización de los maestros, los padres y también la aceptación y la exaltación de las madres.

Las contribuciones de dos autoras judías estadounidenses merecen ser citadas en este ámbito, Judith Plaskow con su trabajo Standing again in Si$n a i^{4}$ y Rachel Adler con su obra Engendering Judaism ${ }^{5}$. El proyecto teológico

3. LÉVINAS, Emanuel. Dios, la muerte y el tiempo, Madrid, Altaya, 1999, p. 147.

4. PlASKOW, Judith, Standing again at Sinai, Judaism From a Feminist Perspective, New York, USA, HarperCollins Publishers, 1990.

5. ADLER Rachel, Engendering Judaism: An Inclusive Theology and Ethics, Philadelphia, PA, USA, The Jewish Publication Society, 1988. 
feminista judío es por su característica intrínseca más impreciso que el de las teólogas cristianas $^{6}$, si es que puede hablarse de un proyecto como tal.

La mujer que ha accedido en los últimos decenios al estudio de la Torá y de la Halajá (Ley Judía) así como a una serie de posiciones en el mundo religioso descubre que no puede verse reflejada en un Dios-varón. El Dios de los Ejércitos, el Todopoderoso, abre paso a antiguas y relegadas imágenes que están allí como pidiendo ser rescatadas, así como a nuevos decires que respondan a sus actuales aspiraciones espirituales.

El hombre a partir de la Creación es femenino y masculino, y de esta doble imagen se desprende no sólo la igualdad de los géneros sino la esencia de la imagen de Dios

Creó, pues, Dios al hombre a imagen suya, a imagen de Dios lo creó; varón y hembra los creó ${ }^{7}$.

Este es el libro de las generaciones de Adán. El día que Dios creó al hombre, a semejanza de Dios lo hizo. Varón y hembra los creó, y los bendijo, y los llamó Adam el día que fueron creados $^{8}$.

Adam, el Hombre, la categoría humana, es creado varón y hembra, ambos a semejanza de Dios. Dos que parecían se parte de una sola esencia. Ya el midrash ${ }^{9}$, muy tempranamente, y otros comentaristas después hacen referencia a la creación de un sólo ser que es en principio hombre y mujer utilizando el concepto griego de «andrógeno», -bisexual-, que sólo se separa posteriormente en dos seres con sexos diferentes. Teniendo en cuenta que el concepto de imagen hace referencia conforme a la mayor parte de los exégetas a las características racionales y/o morales del Creador, y no a su perfil en el sentido material, podríamos pensar entonces la esencia de Dios como un todo, que contiene lo femenino y lo masculino. Él es Todo. A partir de esta idea se puede dar pie a una mirada diferente acerca del eje secuencial de lo masculinofemenino. Los sabios ${ }^{10}$ insinúan en el midrash lo que el discurso del siglo XXI

6. Ver: ADLER Rachel, «Introduction», Engendering Judaism: An Inclusive Theology and Ethics, Philadelphia, PA, USA, The Jewish Publication Society, pages xiv-xxi, 1988.

7. GENESIS 1:27

8. GÉNESIS 5, 1-2.

9. Ver Montaner, Luis Vegas, (Trad. y Ed.) Génesis Rabbah I, Génesis, Párrafo 8, España, Verbo Divino, pág.109, 1994: «...Dijo rabí Irmiah ben Elazar, cuando el Santo Bendito creó al primer Adán, lo creó andrógeno, como está escrito «lo creó varón y hembra». Dijo Rabí Shmuel ben Najman, cuando..., lo creó le dio dos faces, y lo aserró, y le hizo dorsales en cada dirección poniendo uno para un lado y el otro para el otro... y la palabra tzela que se traduce comúnmente como costilla debe interpretarse en la descripción de la construcción del tabernáculo, como barra de sostén.

10. Cuando usamos el término sabios, nos referimos a jaza»l, el acrónimo de las palabra hebreas jajamim zijronam livrajá, -nuestros sabios de bendita memoria-, que aparecen 
parece redescubrir acerca de la dualidad de las facetas masculino-femenino, no como antagónicas sino como aspectos de un mismo ser. Conforme al midrash y a gran parte de la mística judía esos seres que fueron «separados» están en permanente búsqueda de unión, y el encuentro del verdadero amor es el encuentro de aquella «mitad» de la cual fuimos separados. Creencia que se mantiene aún hoy en el folklore popular, aún sin tener claro el origen de la misma. Recordemos que Dios es conforme a la tradición popular judía también el casamentero, aquel que une a las parejas. En Vaikrá (Levítico) Rabáa ${ }^{11}$, encontramos este texto conocido como «Rabí Iosi y la matrona»:

Una matrona le preguntó a rabí Iosef ben Jalufta, ¿en cuántos días creó el Santo Bendito el universo? -le contestó que seis... siguió la matrona: -y ¿desde ese entonces qué hace? -le dijo: compagina parejas, la mujer de fulano a mengano, la hija de fulano para zutano,... -yo puedo hacer lo mismo... -lo que te parece tan fácil es una tarea tan ímproba para el Creador como partir las aguas del Mar Rojo...

Cuando rabí Iosi adjudica a la Divinidad la función de unir parejas, le estaba otorgando la tarea de la casamentera, función que con el tiempo se convirtió en una profesión ocupada exclusivamente por mujeres. La casamentera es una figura importante dentro del folklore judío, y continúa ocupando un papel activo dentro de los sectores más observantes de la sociedad judía.

Todas las creaturas son creadas a imagen y semejanza. La díada HombreMujer es parte de un mismo Ser. Dios es más allá del género, Dios es metasexual, asexual, lo que hace resaltar más aún que el tema que nos convoca no es Dios sino el discurso acerca de Dios. El discurso es de hombres, predicadores, exégetas, maestros, rabinos. Hay quienes intentan explicar que la masculinización se debe a la ausencia del artículo neutro en el idioma hebreo, esta explicación no es suficiente. Dios es Él y no Ella y el discurso refleja las concepciones y aspiraciones del género. Parafraseando a Simone de Beauvoir $^{12}$, no se nace Dios Padre, se llega a serlo. Así la comprensión acerca de Dios, las metáforas y las imágenes, también las femeninas, son vistas a partir del prisma de la visión masculina. La Torá, la shejiná (Divina Presencia que se traduce también como gloria y radiancia divinas), la jojmá (sabiduría), y el Shabat (el día séptimo), sin duda, las tres figuras femeninas, son planteadas

en los escritos desde la Mishná, el Talmud y otros comentaristas de la literatura rabínica, desde los tiempos del Segundo Templo de Jerusalén hasta el siglo sexto.

11. VAikra Raba (Levítico), parashat Tzav, sección 8 inciso a. Jerusalén, Margaliot, 1951-4, siguiendo la edición de Vilnius, Lituania, de 1878.

12. La frase "No se nace mujer, llega una a serlo» abre el famoso escrito de Simone DE Beauvoir, El Segundo Sexo 2, México, Ediciones Siglo Veinte - Alianza Editorial Mexicana, 1989. 
más de una vez a partir de un vínculo poco más o menos erótico, siempre desde la perspectiva del varón ${ }^{13}$ : la Torá es penetrada, amada, y ensalzada como objeto sexual femenino.

Es conocido el caso del sabio talmúdico Ben Azay que vivió en Israel entre los años 110-135, que no se casó porque su amor y su pasión estaban dirigidos a la Torá. Así encontramos en la Tosefta de Masejet Yevamot ${ }^{14}$ :

Dijo Rabí Akiva, quien vierta la sangre, es como si anulara la Imagen, como está dicho «quien derrame la sangre del hombre, por el hombre será derramada su propia sangre». Rabí Eleazar ben Azaria, dijo, quien no se reproduce, es como si vertiera sangre y anula la Imagen, como está escrito «quien derrame la sangre del hombre, por el hombre será derramada su propia sangre, porque a la imagen de Dios hizo él al hombre. Y en cuanto a ustedes, sean fructíferos y lleguen a ser muchos, hagan que la tierra enjambre de ustedes y lleguen a ser muchos en ella». Ben Azay dijo que quien no se reproduce, es como si vertiera sangre y anula la Imagen, como está escrito «Cualquiera que derrame la sangre del hombre, por el hombre será derramada su propia sangre, porque a la imagen de Dios hizo él al hombre. Y en cuanto a ustedes, sean fructíferos y lleguen a ser muchos, etc.» Le dijo rabí Eleazar ben Azaria, ¡Ben Azay, tus palabras son amenas cuando salen de quien las practica! Hay quien predica bien y no cumple correctamente y hay quien cumple correctamente y no predica en forma bonita, y Ben Azay habla muy bien sin embargo no cumple. Le contestó, ¿qué haré? Mi alma desea la Torá. Que el mundo siga existiendo por medio de otros.

Otro ejemplo, tal vez más radical:

Dijo rabí Shmuel bar Najmani, lo que está escrito «una amable cierva y una encantadora cabra montesa» (Proverbios 5:19), ¿por qué se asemejan las palabras de la Torá a una amable cierva? Para enseñarnos que tal como la cierva tiene un útero estrecho, y es apreciada por quien la posee [en el sentido sexual] todas las horas como si fuera la primera, así las palabras de la Torá, son apreciadas por sus estudiosos en todas las horas como en la primera. Y se llama cierva amable - porque llena de amabilidad a sus estudiantes. Su mamilla está siempre presta. ¿Por qué se asemejó la palabra de la Torá a un seno?, pues tal cual como el bebé toca la mama y encuentra en ella leche, así las palabras de la Torá, toda vez que una persona las toca, encuentra gusto en ellas ${ }^{15}$.

13. Dos importantes trabajos en ese sentido son los de BIALE, David, Eros VeHaiehudim, Tel Aviv, Israel, Am Oved, 1992 y BOYARIN, Daniel, Carnal Israel: Reading Sex in Talmudic Culture, University of California Press, Berkeley, 1993. Centrado en la mística judía ver: ABrams, Daniel, HaGuf haElohi Hanashi Bakabala (The Female Body of God in Kabbalistic Literature: Embodied Forms of Love and Sexuality in the Divine Feminine, Jerusalem, Israel, Magnes Press, 2004 [in Hebrew].

14. TOSEFTA de Masejet Yevamot Capítulo 8, Halajá 7, Nueva York, Liberman, 1988.

15. Bereshit Rabati, Parashat Veieji, p. 247, Jerusalén, Allbeck, 1967. 
O veamos esta cita:

Ya no se dirá de ti que eres una mujer abandonada por completo; y de tu propia tierra ya no se dirá que está desolada; sino que tú misma serás llamada: Mi deleite está en Ella, y tu tierra: Poseída como Esposa. Porque Dios se habrá deleitado en ti, y tu propia tierra será poseída como esposa ${ }^{16}$. (Cada vez que aparece la palabra sadé-campo, prado, tierra-, se refiere a la mujer, que es considerada sadé).

Cabe preguntarse ¿cuál es el lugar de la mujer en ese mundo de asociaciones eróticas masculinas y en qué medida el acceso de la mujer al estudio de la Torá cambiará no sólo la imagen de ésta sino también la propia imagen de Dios? Ciertas imágenes producen en parte de las mujeres una sensación de alienación, dejándolas fuera del diálogo teológico.

También en el vínculo amoroso de Dios y Kneset Israel -el pueblo de Israel- en el Cantar de los Cantares, Dios es el hombre que ama activamente, nunca la mujer.

«Dibrá Torá kelashón Benei Adam» («habló la Torá en el lenguaje de los hombres»o «la Escritura se acomoda al lenguaje humano») es una expresión reiterada entre los sabios del Talmud y los Rishonim ${ }^{17}$, que explica los antropomorfismos que utiliza la Torá para referirse a Dios. Dios nos sacó con «mano fuerte y brazo extendido», por ejemplo, es una referencia común al poder de Dios, (nótese también que queda claro que es un brazo masculino, casi de un guerrero), Dios Juez, tiene ojos y oídos «Observa tres cosas y no vendrás a pecar: Sabe qué es lo que hay por sobre ti: un ojo que ve, un oído que escucha, y todas tus acciones en el libro son registradas ${ }^{18}$. Maimónides en su tratado La Guía de los Perplejos ${ }^{19}$ explica:

Ya conoces la autorizada sentencia sobre las diversas clases de interpretación relativas a este asunto, a saber que la Escritura se acomoda al lenguaje humano. Esto significa que todo cuanto los hombre pueden entender e imaginarse, al primer intento, se ha aplicado a Dios ( exaltado sea!), el cual por tal motivo ha sido calificado con predicativos que expresan la corporeidad, para demostrar que Él (jexaltado sea!) existe, dado que el común de los mortales únicamente es capaz de concebir a primera vista, a base de un cuerpo

16. Pirkei de RABi Elezer, cápitulo 21, New York, Horev, M. Heiger, 1944, 1946, 1948.

17. RISHONIM es un término hebreo que se refiere literalmente a los «primeros o iniciadores». Fueron los rabinos principales que vivieron aproximadamente entre el siglo XI y el siglo XV, antes de la escritura del Shulján Aruj y luego de los Gueonim. Los eruditos posteriores al Shulján Aruj son conocidos como los «Ajaronim - Los últimos».

18. Mishna, Avot 2, 1

19. MAimónides, Guía de los Perplejos, Parte 1Capítulo 26, Madrid, España, Edición preparada por David Gonzalo Maeso, Editora Nacional, 1983, Pág. 99. 
individual y todo lo que no sea cuerpo, ni se encuentra en Él, en su concepto no existe.

El ser humano puede pensar sólo en categorías de lo que conoce. Que los antropomorfismos predominantes en el discurso sean masculinos se debe al hecho que ese es el Dios descripto a través de la voz del varón. El Dios de las mujeres debería adaptarse al lenguaje y al pensamiento femenino. Las imágenes de madre, nutriente, matriz, útero, parecerían ser más acordes con un discurso femenino acerca de Dios. La experiencia vital de la mujer no ha sido registrada, ni siquiera ha sido considerada como parte de la creación judía durante la historia. La experiencia femenina no ha nutrido imágenes, no ha sido fuente inspiradora.

El judaísmo presenta un decir diversificado, no monolítico. La pluralidad de voces e interpretaciones es parte intrínseca de su visión teológica en tanto todos los miembros del pueblo, hombres y mujeres, estuvieron presentes en la Revelación y Recepción de la Ley en el Monte Sinaí y fueron y son partícipes de su transmisión. Hombres y mujeres oyeron la voz de Dios, pero cada uno escuchó de acuerdo a su capacidad de audición. «La Torá tiene 70 rostros» es uno de los principios fundamentales del estudio que induce a revelarlos.

Una lectura personal, actualizada e individual nos permitirá comunicarnos con el texto intentando un diálogo con él. Así como lo plantea el Talmud:

¿Por qué fueron comparadas las palabras de la Torá con el fuego? «No es mi palabra como el fuego dice Dios» (Jeremías 23:39). Esto es para enseñarte que así como el fuego no arde solo, así las palabras de la Torá no son duraderas si son para el que se encuentra solo $»^{20}$.

De aquí el estudio compartido, el diálogo, el intercambio de ideas. La posibilidad de la interpretación. Con todo, debemos destacar que en este trabajo no haremos referencia al pensamiento místico judío.

El judaísmo ha dialogado permanentemente con el texto bíblico, dando así paso a la creación del midrash y la halajá a lo largo de los siglos. Sin embargo, en todas las generaciones y también en la nuestra, hay quienes se encuentran imposibilitados de hacerlo. $\mathrm{O}$, porque desconocen la llave de acceso del idioma hebreo, o bien, porque les son ajenos los códigos de comunicación y diálogo de las generaciones anteriores. Hay otros que creen que el diálogo y el cuestionamiento no son legítimos, o que están prohibidos, sobre todos si quienes intentan la lectura son mujeres.

Hay quienes por su reverencia exagerada al texto contradicen paradójicamente el espíritu de las Escrituras, impidiendo una lectura más natural,

20. TALMUD, Taanit 7 a, 
propia, espontánea, individual e íntima, tal cual la realizaron los exégetas al presentar invariablemente versiones diferentes e incluso contradictorias en sus interpretaciones.

\section{Consideraciones acerca de las imágenes de Dios Madre y Dios Nutriente}

Dios Madre

«Escúchenme, oh casa de Jacob, y todos ustedes los restantes de la casa de Israel, ustedes los transportados [por mí] desde el vientre, los llevados desde la matriz. $\aleph^{21}$.

Rabí David Kimji, rabino, exégeta y lexicógrafo bíblico, que viviera alrededor de los años 1160 y 1235, más conocido, por su acrónimo Redak, comenta el versículo diciendo que:

...ustedes fueron transportados desde la matriz de sus madres, y así los llevaré y cargaré sobre mí hasta la vejez, es decir que no les abandonaré jamás, incluso en la vejez cuando más se sufre y se necesita de asistencia, es decir que cada vez que pasen por un problema yo los soportaré.

Otro comentarista, Meir Leibush ben Jehiel Mijel Weiser (1809-Kiev,http:// fr.wikipedia.org/wiki/18_septembre 1879), conocido por su acrónimo Malbim, lo explica diciendo «la forma como Dios los lleva es como la de la mujer que carga el fruto de su vientre, que al principio lo acarrea durante los nueve meses del embarazo, y después cuando abandonan su matriz en el nacimiento, los alza en sus brazos».

El midrash rabán ${ }^{22}$, interpreta:

«No puedes hacerlo tú solo» de Éxodo 18:18, diciendo 'rabí Jyia dijo refiriéndose a los gruñones, «No puedo, por mí solo, llevar a todo este pueblo, porque es demasiado pesado para mí» (Números 11:14), «¿Soy yo quien los ha dado a luz?» (id.id), dijo rabí Berajiá en nombre de rabí Levi, 'el Santo Bendito Sea, tu dijiste 'ustedes los transportados [por mí] desde el vientre, los llevados desde la matriz', a ti te resulta agradable cargarlos, le dijo Moisés al pueblo de Israel, por mi vida que puede cargar diez veces y por qué no puedo cargarles, que el Señor su Dios, los ponga sobre los hombros de sus jueces...

En el reclamo de Moisés a Dios resalta la figura de la concepción: «¿Acaso concebí yo a todo este pueblo? ¿Soy yo quien los ha dado a luz, para que me digas: 'Llévalos en tu seno, tal como el que hace de nodriza lleva al niño de pecho', al suelo acerca del cual juraste a sus antepasados? $\aleph^{23}$.

21. ISAÍAS 46:3

22. MidRASH RABa, Deuteronomio Sección 1, parágrafo 10.

23. NÚMEROS 11:12.

Feminismo/s 20, diciembre 2012, pp. 241-257 
«Yo no he parido este pueblo dice Moisés a Dios, Tú los has parido». El rabí y destacado intelectual judío andaluz Abraham ben Meir ibn Ezra, calificado como el Sabio, el Grande, el Admirable, (1092-1167) comenta "iLos he concebido? ¿Soy su madre? ¿Los he parido? ¿Soy su padre?» Y Moshé ben Najmán, Najmánides (1194-1270), rabino judeoespañol sigue a quien fuera un discípulo de los sabios de la tercera generación de la Mishná, en el Siglo II d.e.c y que fuera el autor de la traducción al arameo, llamada Targúm de Babilonia, conocido como Onkelos el Prosélito, en su traducción al versículo de Génesis 49:2624

«Las bendiciones de tu padre ciertamente serán superiores a las bendiciones de las montañas eternas, al adorno de las colinas de duración indefinida. Continuarán sobre la cabeza de José, aun sobre la coronilla de la cabeza del singularizado de entre sus hermanos», que el padre es llamado así porque es quien provoca la gravidez, se dirá que soy su padre o su madre que los hice nacer. Y los comentaristas en el sentido literal dijeron lo contrario, 'yo soy su madre que los concebí y los hice nacer, tal como se lee en I Crónicas 4:17 «Y ella llegó a concebir a Miriam y a Samai y a Isbah el padre de Estemoa» que se embarazó y los nació, o yo soy su padre que los hizo nacer como aparecen en Génesis 6:10: «Con el tiempo Noé llegó a ser padre de tres hijos: Sem, Cam y Jafet», como en Proverbios 23:22: «Escucha a tu padre, que causó tu nacimiento, y no desprecies a tu madre simplemente porque ha envejecido». Y como dice « ¿He concebido yo mismo a todo este pueblo? ¿Soy yo quien los ha dado a luz, para que me digas: 'Llévalos en tu seno, tal como el que hace de nodriza lleva al niño de pecho', al suelo acerca del cual juraste a sus antepasados?» Padre o madre, y según mi pensamiento, todo, es una forma de expresión referida a la madre, y su razón, es como «He concebido yo mismo a todo este pueblo» y recordó que la mujer es la que sufre el dolor de la crianza de los hijos, desde que los llevó en su matriz y durante su embarazo, y está escrito «artífice» como si fuera en masculino y no en femenino.

La idea de Dios que puede ser madre, que concibe y embaraza aparece también en el conocido poema litúrgico que se lee durante la festividad de Rosh Hashaná, fiesta que entre otras cosas festeja la Creación, el nacimiento del Hombre: Hayom Harat Olam, «Hoy ha sido concebido el mundo» que puede traducirse también como «Hoy es el día del parto del mundo».

Dice el poema:

Hoy es el día del nacimiento del mundo, hoy es juzgada toda la humanidad, ya como hijos, ya como siervos. Si como hijos, ten misericordia de nosotros como un padre tiene misericordia de sus hijos. Si como siervos, nuestros ojos

24. Los intérpretes juegan con palabras del texto hebreo que pueden ser referidas indistintamente al padre o a la madre 
te imploran que seas bondadoso con nosotros y pronuncies clara como la luz nuestra sentencia, tú, que eres reverenciado y santo.

En un excelente artículo, Sara Friedlender Ben-Arza explica lo inusual del uso de esta expresión. En este poema, la Creación del Mundo aparece como un acto de nacimiento, de alumbramiento y de nacimiento. La expresión se basa, conforme al análisis de Ben Arza, en los versículos de Jeremías en los cuales maldice su propio nacimiento:

Maldito el día en que nací; el día en que me dio a luz mi madre no sea bendito. Maldito el hombre que dio la noticia a mi padre, diciendo: ¡Te ha nacido un hijo varón!, haciéndolo muy feliz. Sea ese hombre como las ciudades que el Señor destruyó sin piedad; oiga gritos de mañana y alaridos al mediodía, porque no me mató en el vientre para que mi madre hubiera sido mi sepultura, y su vientre embarazado para siempre ${ }^{25}$.

La expresión HARAT OLAM, embarazada para siempre, es llevada en el lenguaje de los sabios y del poeta hacia otra acepción. Olam puede significar eternidad, diuturnidad, e inmortalidad. Olam es también la palabra hebrea que significa el mundo, el orbe y el cosmos. Si recurriéramos al versículo 20:17 de Jeremías «¿Por qué no me dio muerte definitivamente desde la matriz, para que mi madre llegara a ser para mí mi sepultura, y su matriz estuviera preñada hasta tiempo indefinido» veríamos como HARAT OLAM se transforma en el poema litúrgico en el embarazo del mundo desde la matriz preñada, y conforme a la forma verbal utilizada en el nacimiento o el parto del mundo ${ }^{26}$ lo que en el texto bíblico es tiempo «para siempre» se convierte en espacio, «el mundo» y el embarazo, no en un proceso continuo en el que Jeremías pide perpetuar sino en una acción de parto, nacimiento, relacionada al día «Hayom», al Día del Juicio.

De manera significativa, los sabios establecieron que el Día del Juicio, que es el Día del Nacimiento del Hombre, las lecturas correspondientes de la Torá en la sinagoga son las relacionadas con la esterilidad de Sará, la expulsión de Hagar e Ishmael, en el primer día y en el segundo la atadura de Itzjak. El primer día se cierra la lectura con un capítulo de los Profetas que trae con el episodio de la esterilidad de Janá y al día siguiente con el que presenta el llanto de Rajel, la matriarca estéril. Independientemente de cualquier otra interpretación, podemos concluir que los sabios al normar estas lecturas para el día establecieron la conexión del mismo con dos imágenes, por un lado

25. JEREMÍAS 20:14-17.

26. Ver Ben-ARZA, Sara, «Hayom Harat Olam, al leidat haolam beRosh Hashaná», (Acerca del nacimiento del mundo en Rosh Hashaná) <http://www.piyut.org.il/articles/449.ht$\mathrm{ml}>$ revisado el día 12 de julio de 2012 . 
la del padre del cual los hijos se apartan o son apartados y por el otro el refuerzo de la imagen del nacimiento, Janá, Rajel y Sara, quedaron grávidas ese día conforme la versión del midrash ${ }^{27}$. Dios aparece aquí no sólo con quien concibe en sí mismo y da a luz, sino como quien posee la facultad de dotar de fertilidad a las mujeres.

\section{Dios nutriente - proveedor de alimentos}

En las bendiciones cotidianas se destacan algunas expresiones que destacan ciertas facetas de la imagen de Dios, también si con el correr de los siglos nos hemos acostumbrado a pensarlas en masculino. Dios es el que da alimentos, Dios es el que nutre. De más está marcar el vínculo entre nutrición y maternidad. Dios es la madre que alimenta a su pueblo en el desierto, y en la mesa cada día. Antes de ser quien tiene el dominio sobre las lluvias y el trigo, es Él mismo la raíz nutriente. La nutrición cumple en la vida del hombre no sólo una función fisiológica, sino también establece un vínculo de sostén y protección. El niño alimentado por la madre recibe el calor, la protección, el sostén. Es de notar, por ejemplo, que en las traducciones al devocionario judío la palabra hebrea «lazun» de la raíz «zan»-nutre-, es traducida directamente como sostén, lo que hace que pierda la connotación de nutriente:

BENDITO SEAS, Dios nuestro, rey del universo que sustentas (nutres) al mundo con amor, gracia y misericordia. Él es, en efecto, quien provee de pan a toda criatura. Gracias a su bondad no nos falta nutrición y esperamos que también así sea en adelante. Eterna es su merced y majestuoso es su poder. Bendito seas, Dios nuestro, que a todos sustentas (nutres). Démoste gracias, Dios nuestro, por la buena tierra, tan ubérrima y amena, que has dado a nuestros antepasados por heredad perpetua. $\mathrm{Y}$ te añadimos expresiones de gratitud por habernos liberado de Egipto, casa de servidumbre, así como también por el pacto que has sellado en nuestra carne ${ }^{28}$.

Otra versión, popular, nos dice:

Bendito Seas Señor, Nuestro Dios, Rey del Universo, que a nosotros y a todo el mundo sustentas (nutres), por Tu bondad, Tu clemencia, Tu gracia y misericordia. El da pan a todo lo creado. Su misericordia es eterna. Por su gran bondad, nunca nos falte, ni faltará (alimento) sustento, para siempre jamás. Porque El sustenta (nutre) y sacia a todos, dándoles felicidad; proporciona sustento para todos los seres que creó. Bendito Seas Señor, que a todos sustentas.

27. Ver por ejemplo IaLKut Shimoni, Parashat Vaiera, Jerusalén, 1980, fiel a la edición de Varsovia, Polonia de 1878.

28. YAGUPSKY, Máximo G. (traducción y notas) SIDUR, Devocionario Judío, Buenos Aires, Argentina, Congregación Israelita de la República Argentina, 1980. 
Una tercera versión de autor desconocido, nos dice:

Bendito eres Tú, Eterno, Dios nuestro, Rey del universo, que alimenta a todo el mundo mediante su bondad, con gracia, benevolencia y con misericordia. Él da comida a toda carne, pues su bondad es eterna. Y por su gran bondad, nunca nos faltó y nunca nos faltará alimento por siempre. Por su gran Nombre, pues Él es un Dios que alimenta y sustenta (nutre) a todos, y hace el bien a todos, y provee alimento para todas sus creaciones que Él ha creado. Bendito eres Tú Eterno que alimenta a todos.

No podemos atribuirles a los traductores la pérdida de la connotación primigenia, sino que rastreando la aproximación de los intérpretes a este versículo puede notarse en general un giro hacia el tema de la alimentación en el sentido más amplio. Lazun deja de ser el que nutre para convertirse en el que alimenta y el que alimenta es también, quien provee los alimentos, aún si los compra en el supermercado. Así el hombre es el responsable de alimentar a su esposa, a sus hijos, etc. El verbo, con el correr de los años, ha quedado más ligado al concepto de la provisión técnica e instrumental del alimento que al concepto de nutrición en su sentido primario, en el cual ocuparía un lugar el seno materno. El alimento materno no necesita, como el maná, en hebreo man, ninguna elaboración. Dios hace caer man del cielo, el pueblo lo recoge y lo consume, de manera natural y directa, igual que en el Jardín del Edén, de los árboles y las plantas. La imagen del Dios del man se me ocurre como la de una gran madre que alimenta. En el Jardín del Edén el alimento viene directo de la madre-tierra. Sólo posteriormente, con la expulsión del Edén, el hombre deberá trabajar para ganarse su hogaza y deberá elaborar el grano para hacer su pan. En ese sentido nos ilustran los intérpretes al referirse al versículo donde aparece el man por primera vez:

Por consiguiente, ocurrió que al atardecer las codornices empezaron a subir y a cubrir el campamento, y por la mañana se había desarrollado una capa de rocío alrededor del campamento. Con el tiempo la capa de rocío se evaporó, y resultó que sobre la superficie del desierto había una cosa fina, hojaldrada, fina como la escarcha sobre la tierra. Cuando alcanzaron a verla los hijos de Israel, empezaron a decirse unos a otros: «¿Qué es?». Pues no sabían lo que era. Por eso les dijo Moisés: «Es el pan que el Eterno les ha dado para alimento ${ }^{29}$.

A lo cual comenta el Malbim, es el pan que el Eterno les ha dado se refiere a que está pronto para ser consumido, sin necesidad de elaboración previa. Así es el pan que el Eterno da, alimento directo.

29. Éxodo 16:13-16.

Feminismo/s 20, diciembre 2012, pp. 241-257 
Y Rabeinu Bajaie, el escritor, poeta y filósofo, místico y ascético, influido por los sufíes musulmanes, que escribiera Los deberes de los corazones, explica en relación a la bendición de después de las comidas en Éxodo 16:

Y en la mañana se saciarán de pan y sabrán que yo soy el Eterno su Dios. Y bendecirán mi nombre sobre el alimento, tal como está escrito en Deuteronomio 8:10 «Cuando hayas comido y te hayas satisfecho, entonces tienes que bendecir al Eterno tu Dios por la buena tierra que te ha dado». Y de aquí dijeron los rabinos de bendita memoria, en Berajot 48 b: «Moshé estableció la bendición de gracias después de la comida cuando comenzó a caer el man, y por ello concluyeron que ese es un precepto perteneciente a la Ley Escrita, y la bendición por el pan, es de la Ley Oral».

La imagen del man que cae del cielo como la leche que mana de forma directa y fluida del seno materno, se refuerza al leer al poeta en los Salmos: «Y dio órdenes a las nubes de arriba, y abrió las mismísimas puertas del cielo. Y siguió haciendo llover sobre ellos man para comer, y el grano del cielo les dio» ${ }^{30}$.

El Dios visto por el salmista, que hace fluir el pan del cielo, es también el que viste a los harapientos, el que libera a los cautivos, el que devuelve la visión a los ciegos, levanta a los caídos, defiende a los extranjeros, a los huérfanos y a la viudas, en definitiva, conoce a los débiles y los reconoce como parte de sus creaturas ${ }^{31}$. Dios, desde este prisma, conoce la experiencia de la opresión, de la discriminación y de la marginación. La voz de la mujer puede encontrar eco en su Voz.

\section{Algunas conclusiones tentativas}

Habrá quién se pregunte ¿Qué importancia tiene recuperar la imagen femenina de Dios? Quien plantee esta pregunta pasa por alto la necesidad espiritual de la mitad del pueblo judío y de la humanidad. La posibilidad de un pensamiento y un lenguaje femenino acerca de Dios no es sólo una cuestión de moda, tendencias, o lingüística, sino que involucra la posibilidad de pensar en Dios de modo tal que también la mujer en su existencia pueda ser parte de ese pensar y ese sentir. Un Dios en el que más allá de las facetas de la fuerza, el juicio, la exigencia del cumplimiento del mandato, da paso a la ternura, a la contención, al acuno y al arrullo, a la justicia verdadera y no únicamente al juicio, al dolor y la ira, la venganza y el enojo. El Dios de Janá, que escucha su plegaria, no es el de Eli, que juzga su expresión.

30. Salmos 78: 23-24.

31. Ver Salmos 146.

Feminismo/s 20, diciembre 2012, pp. 241-257 
El Dios de los Ejércitos es también Dios Madre y Nutriente. El Dios Celoso, y el Dios de Nuestros Padres Abraham, Itzjak y Yaakov, el Dios Misericordioso y Compasivo, es también el Dios de nuestras madres, Sara, Rivká, Rajel y Leá. Es el Dios del amor incondicional, de la madre que lleva en su seno a los hijos. Es el Dios que en el desierto provee al pueblo alimento, de agua, de vestimenta, cargándolo 40 años en su seno, hasta hacerlos entrar en la Tierra Prometida, hasta hacerlos salir del útero-desierto.

Dios pensado por la mujer no es sólo el Dios de las Alturas y los Cielos, sino también Uno que está en la tierra, que nutre, fecunda, y da vida.

Dios pensado por la mujer es la otredad en sí misma. Al ser el Otro por antonomasia nos permite entrar al conocimiento del sí mismo. Es un espejo donde se refleja lo humano. Una aspiración y no únicamente una exigencia. Un desafío, y no sólo un mandamiento.

\section{Referencias Bibliográficas}

ABrams, Daniel, HaGuf haElohi Hanashi Bakabala (The Female Body of God in Kabbalistic Literature: Embodied Forms of Love and Sexuality in the Divine Feminine, Jerusalem, Israel, Magnes Press 2004 [in Hebrew].

ADLER Rachel, Engendering Judaism: An Inclusive Theology and Ethics, Philadelphia, PA, USA, The Jewish Publication Society, 1988.

Biale, David, Eros VeHaiehudim, Tel Aviv, Israel, Am Oved, 1992

Boyarin, Daniel, Carnal Israel: Reading Sex in Talmudic Culture, University of California Press, Berkeley, 1993.

De Beauvoir, Simone, El Segundo Sexo, México, Ediciones Siglo Veinte - Alianza Editorial Mexicana, 1989.

Hauptman, Judith, Rereading the Rabbis - A Woman's Voice, Colorado, USA, Westview Press, 1998.

LÉVINAS, Emanuel. Dios, la muerte y el tiempo, Madrid, Altaya, 1999.

PlASKOW, Judith, Standing again at Sinai, Judaism from a Feminist Perspective, New York, USA, HarperCollins Publishers, 1990.

Ross, Tamar, Armon Hatora Memaal La-Al Ortodoxia Ufeminism (Expanding the Palace of Torah-Orthodoxy and Feminism, Tel Aviv, Israel, Am Oved/Alma, 2007.

SAFRAI, Hana, «Dmut Hael - Guisha Feministit Lamasoret HaIehudit» (La imagen de Dios-Un acercamiento Feminista a la Tradición Judía), en SHILO, Margalit (ed.) Lihiot Isha Iehudia - To Be a Jewish Woman - Vol. 2, Jerusalén, Israel, 2001.

OPPENHEIM Michael. Speaking/Writing of God: Jewish Philosophical Reflections on the Life with Others, State University of New York Press, 1997. 